\title{
A missense mutation in the coding region of the toll-like receptor 4 gene affects milk traits in Barki sheep
}

\author{
Ahmed M. Sallam ${ }^{1, *}$
}

* Corresponding Author: Ahmed M. Sallam Tel: + 20-2-263-74800, Fax: +20-2-263-7858,

E-mail: ahmedsallam2@gmail.com

${ }^{1}$ Animal and Poultry Production Division, Desert Research Center, Cairo 11735, Egypt

\section{ORCID}

Ahmed M. Sallam

https://orcid.org/0000-0001-9072-785X

Submitted Dec 30, 2019; Revised Mar 12, 2020; Accepted Jun 14, 2020
Objective: Milk production is one of the most desirable traits in livestock. Recently, the toll-like receptor (TLR) has been identified as a candidate gene for milk traits in cows. So far, there is no information concerning the contribution of this gene in milk traits in sheep. This study was designed to investigate the TLR 4 gene polymorphisms in Barki ewes in Egypt and then correlate that with milk traits in order to identify potential single nucleotide polymorphisms (SNPs) for these traits in sheep.

Methods: A part of the ovine TLR 4 gene was amplified in Barki ewes, to identify the SNPs. Consequently; Barki ewes were genotyped using polymerase chain reaction-single strand conformation polymorphism protocol. These genotypes were correlated with milk traits, which were the daily milk yield (DMY), protein percentage (PP), fat percentage (FP), lactose percentage, and total solid percentage (TSP).

Results: Age and parity of the ewe had a significant effect $(\mathrm{p}<0.05$ or $\mathrm{p}<0.01)$ on DMY, FP, and TSP. The direct sequencing identified a missense mutation located in the coding sequence of the gene (rs592076818; c.1710C >A) and was predicted to change the amino acid sequence of the resulted protein (p.Asn570Lys). The association analyses suggested a significant effect $(p<0.05)$ of the TLR genotype on the FP and PP, while the DMY tended to be influenced as well $(\mathrm{p}=0.07)$. Interestingly, the presence of the $\mathrm{G}$ allele tended to increase the DMY $(+40.5 \mathrm{~g} / \mathrm{d})$ and significantly $(\mathrm{p}<0.05$ or $\mathrm{p}<0.01)$ decreased the FP $(-1.11 \%)$, PP $(-1.21 \%)$, and TSP $(-7.98 \%)$.

Conclusion: The results of this study suggested the toll-like receptor 4 (TLR4) as a candidate gene to improve milk traits in sheep worldwide, which will enhance the ability to understand the genetic architecture of genes underlying SNPs that affect such traits.

Keywords: Association Analysis; Milk Traits; Single Nucleotide Polymorphisms (SNP); Single Strand Conformation Polymorphism (SSCP)

\section{INTRODUCTION}

The dairy sheep industry plays an important role in the economics of several countries especially in the Mediterranean area. Compared to goat and cow, sheep milk has unique properties as it contains higher levels of total solids, mineral and vitamin contents [1]. Additionally, it is more nutritious, richer in vitamins $\mathrm{A}, \mathrm{B}$, and $\mathrm{E}$, calcium, phosphorus, potassium and magnesium, and has a health benefit as it contains a higher portion of short and medium fatty acids chains [2]. On the other hand, it has a positive impact on the newborn lambs, in which good milk supply from the mother may increase the growth rate in the lambs [3].

The Egyptian dairy production industry in predominantly based on cows and buffaloes, with little concern for sheep and goats. This is may be due to [4] the management system of the milk-producing animals in Egypt, which is often the subsistence and smallholder systems. However, sheep contribute about 98,570 tonnes of milk, which is about $5 \%$ of the 
total whole milk produced annually in Egypt with a reasonable increase in the total milk production from sheep in the last few years (Figure 1; http://www.fao.org/faostat/en/\#data). Moreover, sheep milk is preferable for the Bedouin and contributes a substantial part of their livelihood. Unfortunately, there are negative perspectives concerning the small potential for milk production of the Egyptian sheep, which influences their inclusion in the breeding objectives and selection programs. In Egypt, Barki sheep are considered as one of the three major sheep breeds [5]. They are dominate in the North Western Coastal Zone, extending from the Libyan boarders to the west of Alexandria of Egypt with a total of population near to 406,360 [6], which is estimated to be about $8 \%$ of the total number of sheep population in Egypt (http://www.fao.org/faostat/en/\#data). Barki sheep are well adapted to live and produce under hard conditions of shortage food supply and water resources.

Recently, several genotyping technologies of single nucleotide polymorphisms (SNPs) have been used to identify markers associated with specific phenotypes [7,8]. Milk production traits are important targets for genetic improvement and early predictions using genetic markers are therefore important criteria in livestock breeding. Genetic polymorphisms in several genes associated with milk traits in livestock have been reported. The importance of these variants is due to their effect on milk production, composition and quality. Consequently, identifying genetic markers that are associated with the desired phenotype could be helpful in selection programs in livestock [8].

The toll-like receptor 4 (TLR4) is one of the TLRs families, which are known as pathogen-recognizing molecules. Recently, a number of studies reported the association between TLR4 polymorphisms and lactation persistency in Canadian dairy cattle [9], percentages of fat and protein in milk in Irish cattle [10], somatic cell score and 305-day milk yield in Iranian
Holstein cattle [11], and milk yield and fat percentage in Holstein cows in New Zealand [12]. Nevertheless, these associations have neither reported nor studied in sheep.

The ovine TLR4 gene is located on chromosome 21 and consists of 9,069 base pairs and 9 exons and introns. Information regarding the genetics of sheep milk is scarce in the Egyptian breeds. The objective of this study was to identify genetic variants potentially associated with milk traits in Barki sheep, which may be used to make predictions about the superior ewes kept for dairying, selection programs and genetic improvement strategies in sheep in Egypt and worldwide.

\section{MATERIALS AND METHODS}

\section{Ethics statement}

All procedures were conducted and approved by the Animal Care and Use Committee of Desert Research Center, Egypt, and comply with the guidelines and regulations of the Animal Ethics Committee Institute of the European Parliament for protection of experimental animals (2010/63/EU).

\section{Animal resources and phenotypes}

This work was carried out at the facilities of Maryout and Matrouh Research Stations and the Animal Molecular Genetics Laboratory, which both belong to the Animal and Poultry Production Division at Desert Research Center (DRC). Approximately 311 milk-producing ewes were recorded during the season of 2017 through 2018 for the following milk traits: daily milk yield (DMY), total fat percent (FP), total protein percent (PP), lactose percent (LP), and total solid percent (TSP). The milk composition was analyzed using a MilkoScan (130 A/SN. Foss Electric, Hilleroed, Denmark).

The test-day protocol was considered to collect milk records. The milk yield was recorded biweekly from the time of parturition till the 12th week using hand-milking tech-

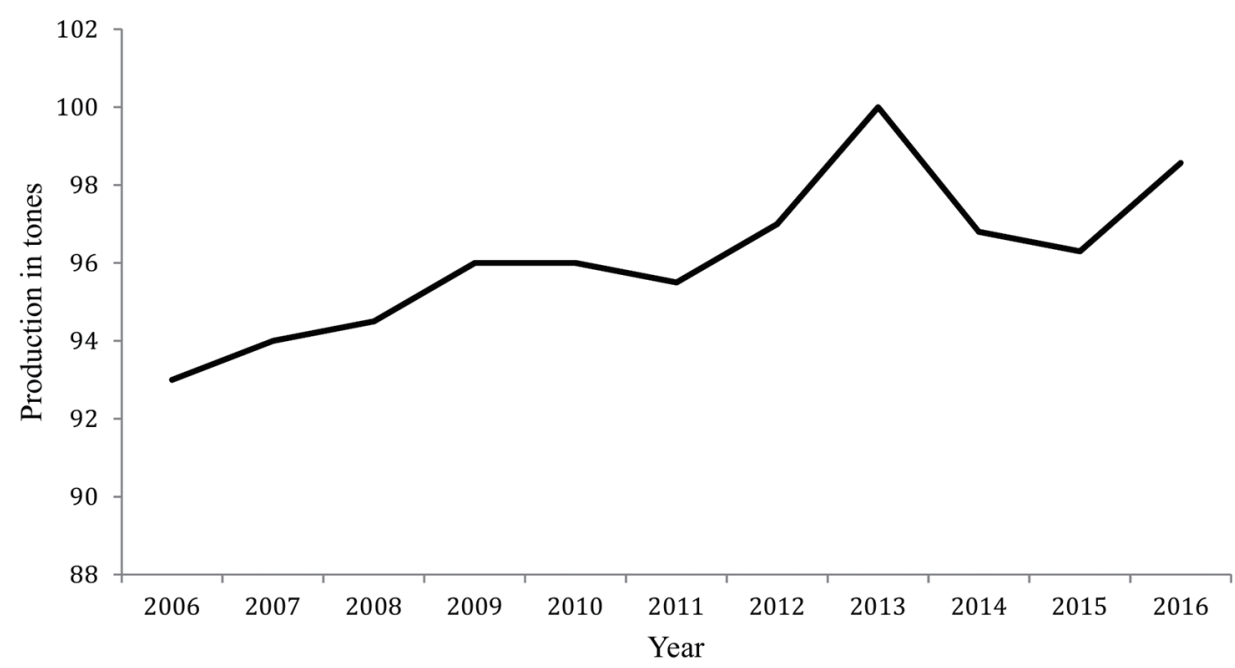

Figure 1. Total production of sheep milk in the last ten years in Egypt retrieved from FAO statistics database (http://www.fao.org/faostat/en/\#home). 
nique. Lambs were separated from their dams $12 \mathrm{~h}$ before milking. Then, right half of the udder was milked in the morning by hand while the lambs were allowed to suckle from the left half. Another milking was carried out in the evening by the same way starting with the left udder. Milk yield per day was measured accordingly in milliliter by summation the morning and evening milking multiplying by two. Of the 311 ewes originally were available for blood collection and genotyping, the phenotypic records were available for about 256 ewes, which were milking producing ewes, and were included in the subsequent association analyses.

\section{Genetic analysis}

Selection of the candidate gene: The TLR4 is a newly identified candidate gene for milk production traits in Holstein cattle in New Zealand [12] and other cattle breeds worldwide. In sheep, the gene has not been characterized or investigated for its contribution to milk traits yet. Based on protein sequence of Ovis aries of the selected gene, the following similarities were obtained by comparing of the amino acid sequence of the gene with three other animal species (Table 1).

Genotyping and identifying the polymorphisms: Genomic DNA was extracted from the whole blood samples using Intron bio (commercial kits, Germany) following the manufactures protocol. Finally DNA samples were stored in a laboratory freezer at $-20^{\circ} \mathrm{C}$. A part of the Ovis aries TLR 4 gene (GeneBank: DQ922636.1) was amplified by polymerase chain reaction (PCR) using the following specific forward and reverse primers: F: 5 - ${ }^{1309}$ TCAGGTGCTGAATATGAG TCA $^{1309}-3$ ' and R: 5- ${ }^{1742}$ CTCTCACCCCTGCCATACTT ${ }^{1761}$ -3' (https://www.ncbi.nlm.nih.gov/gene/?term=DQ922636.1). The PCR products (453 bp) were amplified using thermal cycler apparatuses in tubes containing a $12.5 \mu \mathrm{L}$ of PCR mixture containing $0.8 \mathrm{U}$ Taq DNA polymerase (Qiagen, Hilden, Germany). To amplify the target region, the PCR conditions were as follows; initial step of one cycle of $5 \mathrm{~min}$. at $95^{\circ} \mathrm{C}$, followed by 35 cycles of $1 \mathrm{~min}$ at $95^{\circ} \mathrm{C}, 1 \mathrm{~min}$ at $58^{\circ} \mathrm{C}, 1 \mathrm{~min}$ $30 \mathrm{~s}$ at $72^{\circ} \mathrm{C}$ with final extension of $10 \mathrm{~min}$ at $72^{\circ} \mathrm{C}$. The amplified regions were detected and confirmed using agarose gel electrophoresis.

PCR-single strand conformation polymorphism (SSCP) technique was used to genotype the ovine TLR4 in Barki ewes. Briefly, a $15-\mu \mathrm{L}$ aliquot of each amplicon was denatured at $95^{\circ} \mathrm{C}$ for $5 \mathrm{~min}$, the samples were placed in wet ice and immediately loaded onto $12 \%$ acrylamide: bisacrylamide (37.5:1; Bio-Rad, Hercules, CA, USA) gels. Electrophoresis for $18 \mathrm{~h}$ in $0.5 \times$ Tris/borate/ethylenediaminetetraacetic acid (TBE) buffer at $200 \mathrm{~V}$ was undertaken in Bio-Rad Protean II xi cells with water circulation at $25^{\circ} \mathrm{C}$. The gels were silverstained using the method of Zhou et al [12].

\section{DNA sequencing}

To identify the polymorphic SNPs, PCR amplicons representing different SSCP banding patterns were delivered to Macrogen sequencing company (Seoul, Korea) for sequencing in both directions according to the BigDye terminator protocol. DNA sequences for the forward primers were aligned against the reference sequences from NCBIdb for the corresponding amplified region (ie. flanking region, exon). The alignment was also conducted against the sequence of the reverse primer of the corresponding region to ensure that the identified SNP is real and not artifact. Identification of SNPs was performed using 4Peaks software for the pairwise alignment. Subsequently, the screened polymorphic SNPs were compared to the available SNP NCBI database to determine their exact locations in the gene (https://www.ncbi. nlm.nih.gov/gene/?term=DQ922636.1).

\section{Association analysis}

The association analyses between the ovine TLR4 genotypes and milk production traits was performed using the general linear model process in SAS using the following liner model:

$$
\mathrm{Y}_{\mathrm{ijklm}}=\mu+\mathrm{G}_{\mathrm{i}}+\mathrm{Y}_{\mathrm{sj}}+\mathrm{H}_{\mathrm{k}}+\mathrm{e}_{\mathrm{ijklm}},
$$

Where, $Y_{\mathrm{ij} k \mathrm{~lm}}=$ the trait of interest; $\mu=$ the overall mean; $G_{i}=$ the effect of genotype; $Y_{s j}=$ the effect of parity of the ewe (5 parities); $\mathrm{H}_{\mathrm{k}}=$ the effect of age of the ewe ( 5 level: 1st level, animals $\leq 3$ years old; 2 nd level, animals at 4 to 5 years old; 3rd level, animals at 6 to 7 years old; 4th level, animals at 8 years old; and 5th level, animals above 8 years old); and $\mathrm{e}_{\mathrm{ijk} / \mathrm{lm}}$ $=$ random error. The age of dam and parity were included in the model, while the type of birth (singles or twinning) was not considered, as all births were singles.

Additionally, the additive (A) and dominant (D) effects of each genotype were tested. Accordingly, the genotype effect was divided into $\mathrm{A}$ and $\mathrm{D}$ effects as follow:

Table 1. Comparative analysis of amino acid sequences of the selected genes in different species

\begin{tabular}{lllc}
\hline Gene & Organism & Accession number & Similarity ${ }^{\text {1) }}$ \%) \\
\hline TLR (Ovis aries) (NP_001108139.1) & Arabian camel & XP_010977688.1 & 86 \\
& Buffalo & XP_006068111.1 & 96 \\
& Bos taurus & NP_776739.1 & 93 \\
\hline
\end{tabular}

\footnotetext{
${ }^{1)}$ The similarity alignment was based on Ovis aries (sheep) published on NCBI/BLAST.
} 
The additive effect $(\mathrm{A})=\frac{\mathrm{GG}-\mathrm{TT}}{2}$

The dominant effect $(\mathrm{D})=\mathrm{GT}-\frac{\mathrm{GG}+\mathrm{TT}}{2}$

Where, GG, GT, and TT represent the least square means of the corresponding genotypes, respectively.

\section{RESULTS}

\section{Descriptive statistics and selection of the candidate} gene

Results of protein sequence similarity in the three species suggested a high similarity of the gene (Table 1), which means that this gene may be a good target to be investigated in sheep. The milk production traits for Barki ewes included in the current study are described in Table 2. The DMY ranged from 0.07 to $0.88 \mathrm{~kg} / \mathrm{d}$ with an average of $0.31 \pm 0.13 \mathrm{~kg} / \mathrm{d}$. The FP

Table 2. Descriptive statistics of the milk production traits in Barki ewes

\begin{tabular}{lcccc}
\hline Item & Average & SE & Minimum & Maximum \\
\hline DMY $(\mathrm{kg} / \mathrm{d})$ & 0.31 & 0.13 & 0.07 & 0.88 \\
$\mathrm{FP}$ & 4.63 & 0.15 & 1.45 & 11 \\
$\mathrm{PP}$ & 5.51 & 0.14 & 1.75 & 10 \\
$\mathrm{LP}$ & 6.37 & 0.16 & 1.02 & 10 \\
TSP & 17.27 & 0.66 & 2.55 & 35 \\
\hline
\end{tabular}

$n=233$ ewes.

$\mathrm{SE}$, standard error; DMY, daily milk yield (g/d); FP, fat percentage; $\mathrm{PP}$, protein percentage; LP, lactose percentage; TSP, total solid percentage. ranged from $1.45 \%$ to $11 \%$ with an average of $4.63 \% \pm 0.15 \%$. The PP ranged from $1.75 \%$ to $10 \%$ with an average of $5.51 \%$ $\pm 0.14 \%$. The LP ranged from $1.02 \%$ to $10 \%$ with an average of $6.37 \% \pm 0.16 \%$. The TSP ranged from $2.55 \%$ to $35 \%$ with an average of $17.37 \% \pm 0.66 \%$.

\section{Effect of the age of ewe and parity on the milk traits} The age of ewe and parity significantly influenced the DMY, FP, and TSP (Table 3, Figure 2). Ewes at 3 and 4 years old tended to produce the highest DMY $286.87 \pm 31.37 \mathrm{~g} / \mathrm{d}$ followed by ewes at 5 and $6,253.47 \pm 41.76 \mathrm{~g} / \mathrm{d}$, while the DMY was the lowest from ewes above 8 years old $(174.01 \pm 82.68 \mathrm{~g} /$ d). Similarly, the TSP tended to decrease in milk as the ewe aged, as it was $17.81 \% \pm 1.46 \%, 17.43 \% \pm 1.95 \%$, and $10.66 \% \pm$ $3.53 \%$, for the corresponding levels of age, respectively. Conversely, the FP in milk was the lowest at ages 3 and 4 years old $(4.53 \% \pm 0.55 \%)$ followed by 5 and 6 years old ewes $(4.59 \%$ $\pm 0.41 \%)$ while it was the highest at the above 8 years old ewes $(6.92 \% \pm 0.99 \%)$.

Likewise, the effect of parity of ewe on milk traits was highly significant $(p<0.01)$. Ewes at third parity tended to produce the highest DMY $(340.62 \pm 32.46 \mathrm{~g} / \mathrm{d})$ followed by ewes at the second parity $(256.33 \pm 34.31 \mathrm{~g} / \mathrm{d})$, while the ewes at the fifth parity produced the lowest DMY $(127.36 \pm 94.21 \mathrm{~g} / \mathrm{d})$. Similarly, ewes in the first parity produced the highest TSP in milk $(21.78 \% \pm 2.11 \%)$ compared to those who are in the fifth parity, which produced the lowest TSP (3.60\% $\pm 4.05 \%)$. Conversely, ewes in the second parity produced the highest FP in milk $(6.63 \% \pm 0.45 \%)$ and ewes at the third parity were the lowest FP producers $(5.04 \% \pm 0.43 \%)$.

Table 3. Effect of the non-genetic factors on milk traits in Barki ewes

\begin{tabular}{|c|c|c|c|c|c|c|}
\hline \multirow{2}{*}{ Factor $^{1)}$} & \multirow{2}{*}{$\mathbf{n}$} & \multicolumn{5}{|c|}{ Traits } \\
\hline & & DMY & FP & PP & LP & TSP \\
\hline \multicolumn{7}{|l|}{ Age of ewe } \\
\hline $1 \mathrm{st}$ & 17 & $253.47 \pm 41.76$ & $4.53 \pm 0.55$ & $6.35 \pm 0.54$ & $6.97 \pm 0.65$ & $17.43 \pm 1.95$ \\
\hline 2nd & 48 & $286.87 \pm 31.37$ & $4.59 \pm 0.41$ & $6.29 \pm 0.41$ & $7.08 \pm 0.48$ & $17.81 \pm 1.46$ \\
\hline $3 r d$ & 13 & $237.12 \pm 40.9$ & $6.18 \pm 0.54$ & $5.97 \pm 0.54$ & $7.37 \pm 0.64$ & $17.40 \pm 1.93$ \\
\hline 4th & 14 & $218.77 \pm 46.22$ & $6.61 \pm 0.59$ & $7.34 \pm 0.59$ & $7.75 \pm 0.70$ & $11.47 \pm 2.11$ \\
\hline 5th & 4 & $174.01 \pm 82.68$ & $6.92 \pm 0.99$ & $7.63 \pm 0.99$ & $6.96 \pm 1.17$ & $10.66 \pm 3.53$ \\
\hline Significance & & $0.031^{\star}$ & 0.001 ** & 0.15 & 0.87 & $0.039 *$ \\
\hline \multicolumn{7}{|l|}{ Ewe parity } \\
\hline $1 s t$ & 14 & $206.38 \pm 43.03$ & $5.87 \pm 0.59$ & $6.11 \pm 0.59$ & $6.73 \pm 0.70$ & $21.78 \pm 2.11$ \\
\hline 2nd & 32 & $256.33 \pm 34.31$ & $6.63 \pm 0.45$ & $6.54 \pm 0.45$ & $6.99 \pm 0.53$ & $20.58 \pm 1.61$ \\
\hline $3 r d$ & 30 & $340.62 \pm 32.46$ & $5.04 \pm 0.43$ & $5.83 \pm 0.42$ & $7.0 \pm 0.50$ & $18.93 \pm 1.52$ \\
\hline 4 th & 17 & $139.53 \pm 41.15$ & $5.40 \pm 0.50$ & $6.89 \pm 0.50$ & $5.99 \pm 0.60$ & $9.89 \pm 1.80$ \\
\hline 5th & 3 & $127.36 \pm 94.21$ & $5.90 \pm 1.14$ & $8.20 \pm 1.14$ & $9.37 \pm 1.35$ & $3.60 \pm 4.05$ \\
\hline Significance & & 0.001 ** & $0.035^{\star}$ & 0.28 & 0.17 & 0.0001 ** \\
\hline
\end{tabular}

$n=233$ ewes; predicted least square means \pm standard errors from general linear models.

DMY, daily milk yield (g/d); FP, fat percentage; PP, protein percentage; LP, lactose percentage; TSP, total solid percentage.

1) Levels of age of the ewe: 1 st level, animals $\leq 3$ years old; 2 nd level, animals at 4 to 5 years old; 3rd level, animals at 6 to 7 years old; 4 th level, animals at

8 years old; 5 th level, animals above 8 years old.

* Significance estimated at $p<0.05$ and $p<0.01$ for the highly significant. 


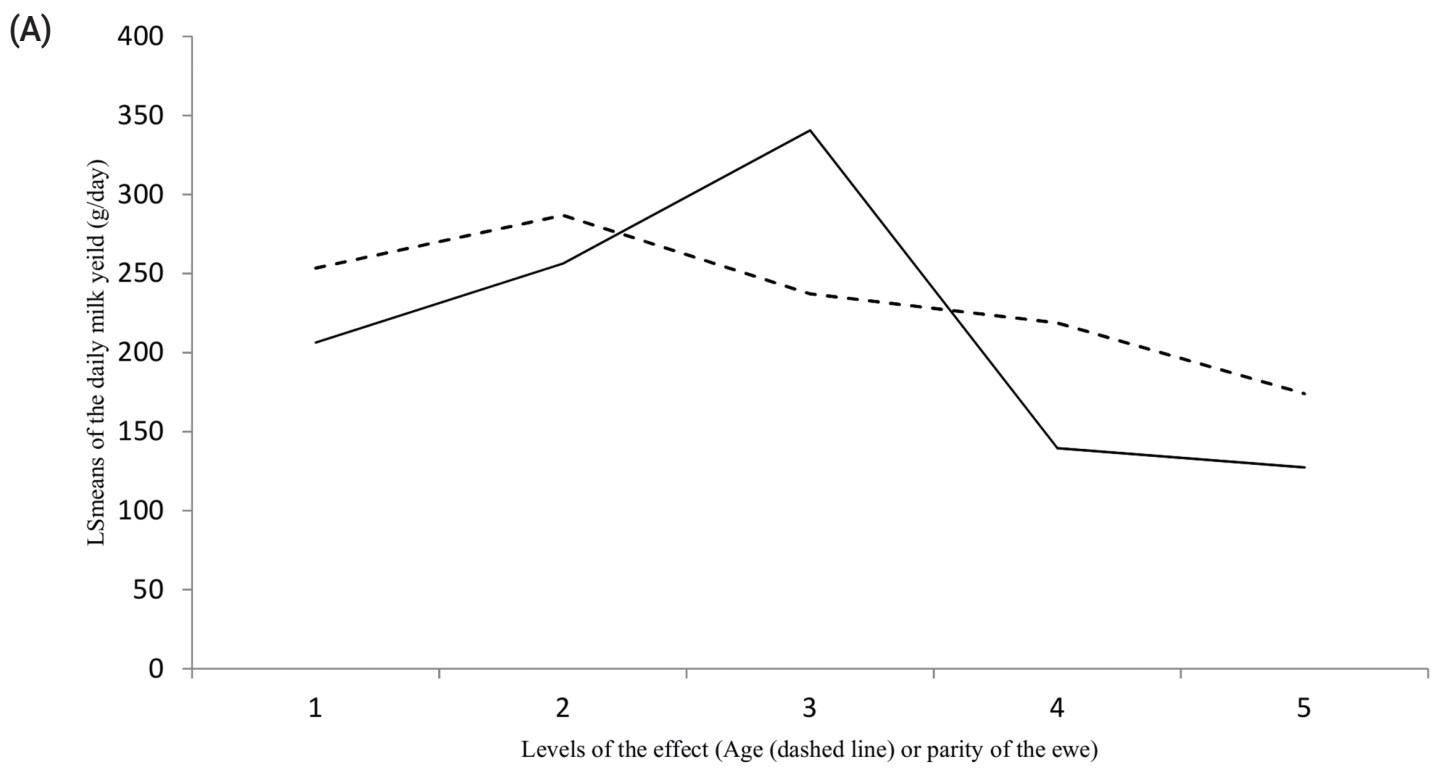

(B)
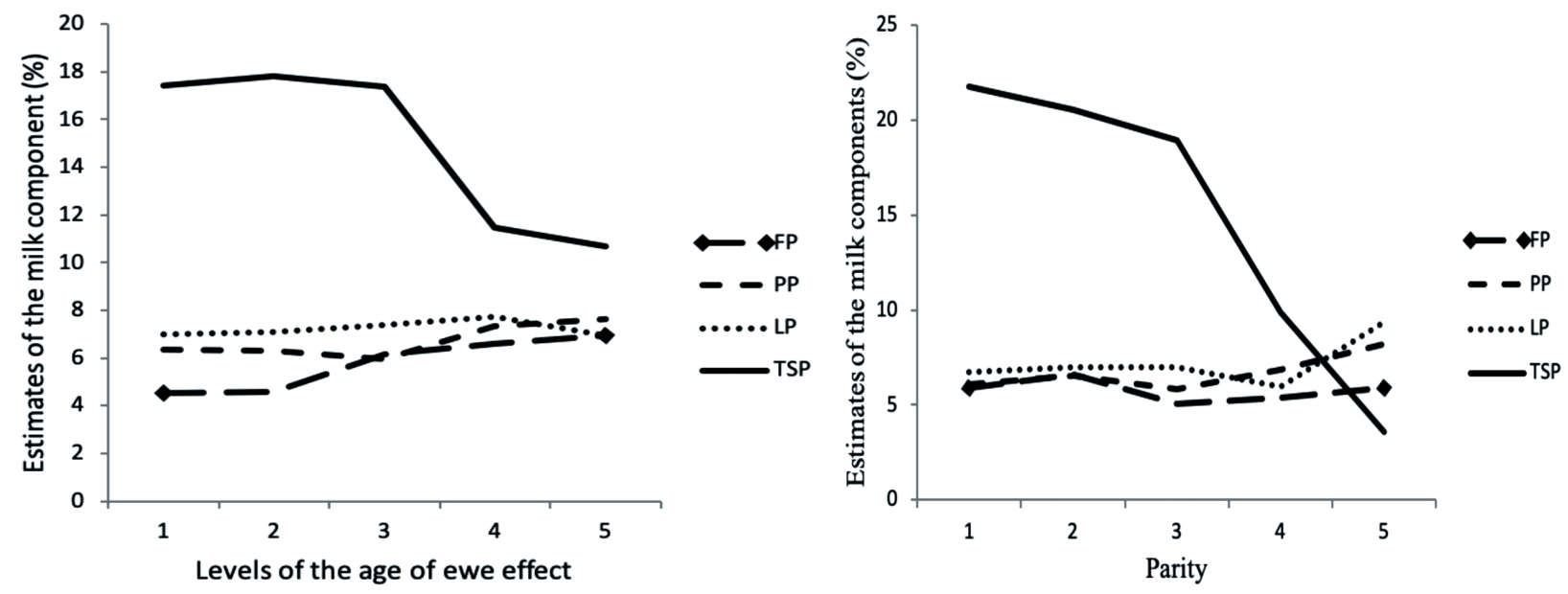

Figure 2. (A) Effect of the age of ewe and parity ( 5 parities) on the daily milk yield, in which age of the ewe had 5 levels: 1 st level, animals $\leq 3$ years old; 2nd level, animals at 4 to 5 years old; 3rd level, animals at 6 to 7 years old; 4th level, animals at 8 years old; 5 th level, animals above 8 years old. (B) Effect of the age of ewes and parity on milk compositions. FP, fat percentage; PP, protein percentage; LP, lactose percentage; and TSP, total solids percentage. The age and parity of the ewe significantly affected $(p<0.05$ or $p<0.01)$ daily milk yield, FP and TSP.

Nevertheless, both factors did not significantly $(\mathrm{p}<0.05)$ affect the percentages of protein (PP) and lactose (LP) in the milk of the Barki ewes.

The toll-like receptor 4 variation in Barki ewes The PCR-SSCP patterns identified two distinctive conformation patterns (named $\mathrm{G}$ and T) in the TLR4 in the investigated ewes (Figure 3). The allelic frequencies were 63.5\% and 36.5\% for $\mathrm{G}$ and $\mathrm{T}$ alleles, respectively. Likewise, the genotypic frequencies were $44.6 \%, 35.7 \%$, and $19.7 \%$ for GG, GT, and TT genotypes, respectively. DNA sequencing results of the representative patterns identified a missense mutation located in the coding sequence of exon 3 of the gene at position 5858783 base pairs of chromosome 2 (ENSOART00000006304.1:
c.1710C $>$ A). Interestingly, the identified SNP (rs592076818) was predicted to change in the amino acid sequence (Figure 4) of the resulted protein (ENSOARP00000006210.1: p.Asn570Lys; https://www.ensembl.org/Ovis_aries/Transcript/).

\section{Effect of variants in toll-like receptor 4 gene on milk traits}

Results of the presence/absence allele model clearly showed that (Table 4) the presence of the G allele increased the DMY (presence: $310.36 \pm 14.12 \mathrm{~g} / \mathrm{d}$, absence: $269.86 \pm 36.14 \mathrm{~g} / \mathrm{d}$ ), however, this effect was not significant $(\mathrm{p}=0.17)$. Moreover, the FP (presence, $4.53 \pm 0.15$; absence, $5.64 \pm 0.16$ ), PP (presence, 5.40 \pm 0.15 ; absence, 6.61 \pm 0.56$)$ decreased significantly $(\mathrm{p}<$ 0.05 ), and TSP (presence, 16.52 \pm 0.70 ; absence, 24.50 \pm 1.6 ) 
TT

GT

TT

0

GT

0

GG

GG

GT

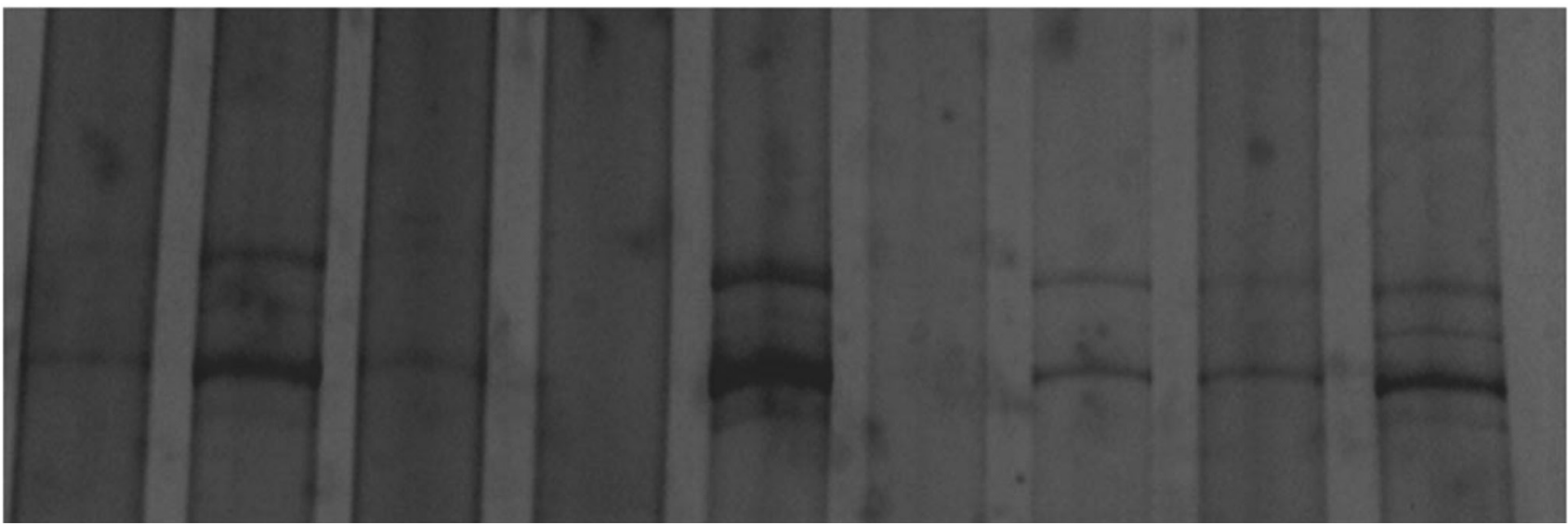

Figure 3. PCR-SSCP patterns of the ovine TLR4 gene in Barki sheep representing G and T alleles and different genotypes. PCR, polymerase chain reaction; SSCP, single strand conformation polymorphism; TLR4, toll-like receptor 4.

(A)

Allele C CAAGAACTACGGAATTT GCCAAGGAACCTCACTTGGCTAAATCTTACTCAGAATGAATT

Allele G CAAGAACTACGGAATTT GCCAAGGAAACTCACTTGGCTAAATCTTACTCAGAATGAATT

(B)

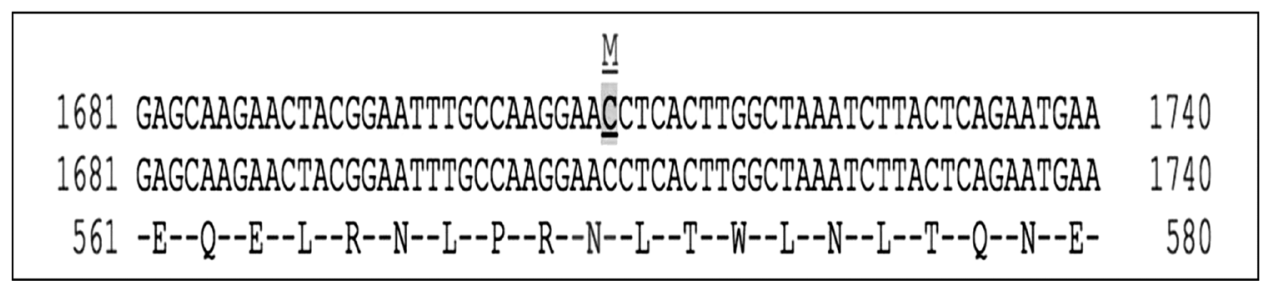

Figure 4. (A) Sequencing results of the ovine TLR4 variants showing the identified SNPs and their locations. (B) The predicted consequences of the identified variant of the ovine TLR4 gene on the resulted protein (ENSOARP00000006210.1: p.Asn570Lys) in Barki sheep from Ensembl (www. ensembl.org). TLR4, toll-like receptor 4; SNPS, single nucleotide polymorphisms.

Table 4. Association of presence or absence of the toll-like receptor variants with milk production traits in Barki ewes

\begin{tabular}{|c|c|c|c|c|c|}
\hline \multirow{2}{*}{ Trait } & \multirow{2}{*}{ Variant } & Presence & Absence & \multirow{2}{*}{ Effect $^{1)}$} & \multirow{2}{*}{$p$-value } \\
\hline & & Mean $\pm S E^{2)}$ & Mean $\pm S E^{2)}$ & & \\
\hline \multirow[t]{2}{*}{ DMY } & $\mathrm{T}$ & $306.51 \pm 22.02$ & $307.05 \pm 14.99$ & -1.46 & 0.31 \\
\hline & G & $310.36 \pm 14.12$ & $269.86 \pm 36.14$ & +40.5 & 0.17 \\
\hline \multirow[t]{2}{*}{$\mathrm{FP}$} & $\mathrm{T}$ & $5.06 \pm 0.26$ & $4.20 \pm 0.16$ & +0.86 & 0.82 \\
\hline & G & $4.53 \pm 0.15$ & $5.64 \pm 0.16$ & -1.11 & $0.022^{*}$ \\
\hline \multirow[t]{2}{*}{ PP } & $\mathrm{T}$ & $6.03 \pm 0.24$ & $4.98 \pm 0.13$ & +1.05 & 0.10 \\
\hline & G & $5.40 \pm 0.15$ & $6.61 \pm 0.56$ & -1.21 & $0.007 * \star$ \\
\hline \multirow[t]{2}{*}{ LP } & $\mathrm{T}$ & $6.66 \pm 0.26$ & $6.07 \pm 0.18$ & +0.59 & 0.56 \\
\hline & G & $6.30 \pm 5.95$ & $7.07 \pm 6.06$ & -0.77 & 0.17 \\
\hline \multirow[t]{2}{*}{ TSP } & $\mathrm{T}$ & $18.23 \pm 1.11$ & $16.22 \pm 0.7$ & +2.01 & 0.94 \\
\hline & G & $16.52 \pm 16.15$ & $24.50 \pm 20.98$ & -7.98 & $0.017 *$ \\
\hline
\end{tabular}

SE, standard errors; DMY, daily milk yield (g/d); FP, fat percentage; PP, protein percentage; LP, lactose percentage; TSP, total solid percentage.

1) Increase (+) or decrease (-) of the corresponding trait.

2) Predicted least square means $\pm S E$ from general linear models.

Significance estimated at $* p<0.05, * \star p<0.01$. 
Table 5. Effect of the toll-like receptor genotypes on milk production traits and composition in Barki ewes

\begin{tabular}{|c|c|c|c|c|}
\hline \multirow{2}{*}{ Trait } & \multicolumn{3}{|c|}{ Genotype (n) } & \multirow{2}{*}{ p-value } \\
\hline & TT (47) & GT (85) & GG (106) & \\
\hline $\operatorname{DMY}(\mathrm{g} / \mathrm{d})$ & $141.96 \pm 44.47$ & $233.76 \pm 28.10$ & $246.42 \pm 31.07$ & 0.07 \\
\hline $\mathrm{FP}$ & $6.88 \pm 0.63$ & $5.07 \pm 0.34$ & $5.35 \pm 0.39$ & $0.024^{\star}$ \\
\hline PP & $7.80 \pm 0.63$ & $6.45 \pm 0.34$ & $5.90 \pm 0.39$ & $0.020 *$ \\
\hline LP & $7.43 \pm 0.75$ & $7.09 \pm 0.41$ & $7.16 \pm 0.42$ & 0.89 \\
\hline TSP & $17.25 \pm 2.25$ & $13.92 \pm 1.24$ & $13.69 \pm 1.41$ & 0.28 \\
\hline
\end{tabular}

$n=233$ ewes.

DMY, daily milk yield (g/d); FP, fat percentage; PP, protein percentage; LP, lactose percentage; TSP, total solids percentage.

* Significance estimated at $p<0.05$.

with the presence of the $\mathrm{G}$ allele. Nonetheless, this model did not show any significant with the T allele.

\section{Effect of variations in toll-like receptor 4 gene on milk traits}

Results of the association analyses of the TLR4 genotypes and milk traits (Table 5) suggested that ewes with the GG genotype significantly produced more milk $(\mathrm{DMY}=246.42 \pm 31.07$; $\mathrm{p}=0.07)$ with lower FP $(5.35 \pm 0.39 ; \mathrm{p}=0.024)$ and $\mathrm{PP}(5.90 \pm$ $0.39 ; \mathrm{p}=0.020)$. In contrary, ewes with the TT genotype significantly produced higher FP (6.88 \pm 0.63$)$, PP $(7.80 \pm 0.63)$, and lower milk production $(\mathrm{DMY}=141.96 \pm 44.47)$. Nonetheless, TLR4 genotypes did not significantly affect the LP and TSP in Barki ewes' milk.

The genetic effects (additive/dominance) of the TLR4 variants on the studied milk traits in Barki sheep are presented in Table 6. The results showed significant additive effects on the FP $(-0.72, \mathrm{p}<0.01), \mathrm{PP}(-0.86, \mathrm{p}<0.01), \mathrm{LP}(-0.49, \mathrm{p}=$ $0.05)$, and TSP $(-2.73, \mathrm{p}<0.01)$. Furthermore, a significant dominance effect was also observed for the TLR4 variants on the PP $(+0.68, \mathrm{p}<0.05)$.

\section{DISCUSSION}

Despite the reported high heritability of milk traits in livestock, which suggests that selection for these traits could be made based on the traditional methods, identifying genetic markers and candidate genes to improve milk traits will assist selecting the superior animals early in their ages with more success [13]. On the other hand, although a number of studies have investigated variations in TLR4 in bovine and its relationship with milk traits, little has been undertaken with this gene in sheep. Accordingly, critical investigations are required to identify the gene variations in sheep and to estimate their effects on milk. This study describes for the first time genetic variants within a part of the ovine TLR4 gene and their association with important milk production traits in Barki ewes.

Overall, the estimates of milk traits reported here in Barki ewes were in agreement with those estimated by Abousoliman et al [3] in Barki sheep and dairy sheep in Slovakia [14]. How- ever, some milk components were dissimilar in the Slovakian ewes ( $\mathrm{FP}=6.91 \%$ vs $4.63 \%$, $\mathrm{LP}=4.54 \%$ vs $6.37 \%$ ) compared with those reported in this study. Likewise, Ozmen and Kul [15] reported different estimates for the FP, PP, and LP in Sakis (7.06, 6.43, and 5.41, respectively), Akkaraman (4.12, 4.02, and 6.11, respectively) and Awassi (5.17, 3.91, and 5.92, respectively) sheep breeds, than those reported here in Barki ewes. Nevertheless, these values were slightly higher than those reported by Balthazar et al [16] in sheep, goat and cows, and in the dairy ewes in the US [17].

Consistent with the results of the current study, the age of ewe and parity significantly $(\mathrm{p}<0.05)$ affected most of the milk production traits and composition in cattle [18], goats [19], and sheep [17,20-22] in different breeds worldwide. Results of the current study showed similar trends of both effects (i.e. age and parity) on milk yield and composition in Barki ewes, in which the younger ewes tended to produce more DMY and TSP and lower FF, PP, and LP compared to older ewes. These findings confirmed the negative correlation between the milk yield and components at different ages and parities. However, a non significant effect of the age of ewe on DMY was reported in Rahmani and Chios breeds in Egypt [20]. According to the results of this study, selection for ewes at 4 years old and the third parity could increase the daily milk production as well.

The only identified SNP in the investigated area of the

Table 6. Genetic effect of the ovine toll-like receptor 4 on milk traits in Barki ewes

\begin{tabular}{lcccc}
\hline \multirow{2}{*}{ Traits } & \multicolumn{4}{c}{ Genetic effect $^{1)}$} \\
\cline { 2 - 5 } & Additive & p-value & Dominance & p-value \\
\hline DMY $(\mathrm{g} / \mathrm{d})$ & 8.10 & 0.69 & 12.90 & 0.63 \\
FP & -0.72 & $0.003^{\star \star}$ & 0.52 & 0.10 \\
PP & -0.86 & $<0.001^{\star \star}$ & 0.68 & $0.02^{\star}$ \\
LP & -0.49 & $0.05^{\star}$ & 0.34 & 0.30 \\
TSP & -2.73 & $0.007^{\star \star}$ & -0.57 & 0.67 \\
\hline
\end{tabular}

DMY, daily milk yield (g/d); FP, fat percentage; PP, protein percentage; LP, lactose percentage; TSP, total solid percentage.

${ }^{1)}$ Increase (+) or decrease (-) of the corresponding trait.

Significance estimated at $* p<0.05, * * p<0.01$. 
TLR4 was lower than the number of SNPs identified in the same corresponding region of the gene in sheep and goats, which were 14 [23] and 4 [24], respectively. This suggests a low genetic diversity in the gene in Barki sheep, which may be because of the high selection pressure for this gene in Barki sheep [12]. This result disagrees with earlier reports that stated that the immune response genes in ovine have a high level of diversity compared to their orthologous genes in bovines [25]. However, only one SNP has been identified (c.2021C/ T; rs8193069) in the coding region of the bovine TLR4 [12]. Moreover, the missense mutation identified here supports the findings of Zhou et al [23] that reported most of the SNPs in this region of the ovine TLR4 were non-synonymous causing amino acid changes and creating a polymorphic protein. A possible reason for that is to guarantee a large amount of diversity in a gene required for disease resistance.

Notably, the identified SNP is located at the 1,710 position of the coding region of the ovine TLR4 region (c.1710C $>$ A), which changes the Asparagine amino acid at position 570 to the lysine in the resulted protein (p.Asn570Lys). Results of the association analysis of the TLR4 genotypes and milk traits support our hypothesis that there is genetic potential for improvement in milk production in Barki sheep. Genetic variations in milk production and composition were clearly observed, which emphasises the importance of finding genetic makers for the marker-assisted selection programs in the breed. So far, there is no study that has investigated the association between TLR4 variants and milk traits in sheep. So that, it is hard to compare the results of the current study taking into account the perspectives of other researchers' findings.

Noteworthy, the association tests showed that the GG genotype positively affected DMY $(246.42 \pm 31.07 \mathrm{~g} / \mathrm{d})$ but negatively affected FP $(5.35 \% \pm 0.39 \%)$ and PP $(5.90 \% \pm 0.39 \%)$ compared to the TT genotype (141.96 $\pm 44.47,6.88 \pm 0.63$, and $7.80 \pm 0.63$, for the corresponding traits, respectively). This means that animals that carry the $\mathrm{G}$ allele produce more daily milk with lower fat and protein percentages, which also supports the previously negative genetic correlation between DMY and milk compositions [26]. These results were compatible with the results of the presence/absence allele model, which clearly showed that the presence of the G allele increased the DMY (presence, $310.36 \pm 14.12 \mathrm{~g} / \mathrm{d}$; absence, $269.86 \pm 36.14 \mathrm{~g} / \mathrm{d}$ ), however, this effect was not significant $(\mathrm{p}=0.17)$, and decreased the FP (presence, $4.53 \pm 0.15$; absence, 5.64 \pm 0.16 ) and PP (presence, 5.40 \pm 0.15 ; absence, $6.61 \pm 0.56$ ).

Importantly, it was suggested that the separation of the genetic variants of a milk-candidate gene into a good and a poor genotypes in relation to milk traits will ease the future breeding towards better milk production and composition [27]. This suggestion could be implied here in the TLR4 variants to achieve the optimum progress in dairy sheep products based on the results of the current report. Recent reports refer to the importance of estimating the additive and/or the dominance genetic effect of specific variants on the economic traits of livestock $[28,29]$. The significant additive effects of the TLR4 variants identified here in Barki ewes on FP, PP, LP, and TSP suggested that these effects should be considered in genetic improvement of milk production in Barki sheep. Moreover, the considerable additive and dominance effects that were observed here for the studied variant on the PP emphasizing the significant of the association and increase the accuracy of the potential prediction of the animal [28]. Similar significant effects of the non-additive genetic models were reported for milk traits in cattle [30].

There is speculation that of the low frequency of the SNP c. $2012 \mathrm{C} / \mathrm{T}$ in the TLR4 gene in the Canadian Holstein [31] is a consequence of natural selection against the allele, as it may cause an immature immune response. This may be a reason for the low frequency of the T allele in Barki sheep as well. Overall, the biological mechanism behind the effect of the TLR 4 on milk traits is still unknown and needs intensive investigations to be understood. However, it could be attributable to the contribution of the gene in specific signaling pathways that influences the expression of major gens for milk traits, which modulates the milk traits as an end product [32]. Another possible explanation is the demonstrated correlation between the TLR polymorphisms and clinical diseases (i.e. mastitis and Johne's disease) in livestock that negatively affect milk quantity and quality $[9,31]$. Thus, the identified TLR4 variants identified here may positively affect milk components by improving the immune response of the animal against the previously mentioned milk diseases. It is important to understand the reasons behind the low frequency of the allele $\mathrm{T}$ in Barki sheep, further investigations for the association of sheep that have the $c .1710 \mathrm{C}>\mathrm{A}$ mutation in context of the immune responses are highly recommended.

Summarizing, this report in presents different perspectives concerning the milk production potentials in the indigenous Egyptian sheep. It confirms the relationship between the TLR4 gene and milk traits in livestock as suggested by several reports, and in sheep for the first time. Importantly, the additive/ dominance modes reported here enables understanding of the inheritance modes of the TLR4 markers in milk traits of sheep in general and Barki in particular. Accordingly, this information may be used to identify the superior animals for successful genetic improvement strategies.

\section{CONFLICT OF INTEREST}

We certify that there is no conflict of interest with any financial organization regarding the material discussed in the manuscript. 


\section{ACKNOWLEDGMENTS}

Financial support for this work, laboratory facilities and animal resources from the Department of Animal and Poultry Breeding Department, DRC are acknowledged. The author also acknowledges the contribution of Adel Ibrahim, Amin M Said and Ibrahim Abousoliman in the wet laboratory work and the consultation of the statistical analyses is gratefully acknowledged.

\section{REFERENCES}

1. Park YW, Juarez M, Ramous M, Haenlin GFW. Physicochemical characteristics of goat and sheep milk. Small Rumin Res 2007;68:88-113. https://doi.org/10.1016/j.smallrumres. 2006.09.013

2. Coni E, Bocca B, Caroli S. Minor and trace element content of two typical Italian sheep dairy products. J Dairy Res 1999; 66:589-98. https://doi.org/10.1017/S0022029999003775

3. Abousoliman I, Reyer H, Oster M, et al. Analysis of candidate genes for growth and milk performance traits in the Egyptian Barki sheep. Animals 2020;10:197. https://doi.org/10.3390/ ani10020197

4. Galal S, Abdel-Rasoul F, Shaat I, Anous MR. On-station characterization of small ruminant breeds in Egypt. In: Luis I, editor. Characterization of small ruminant breeds in West Asia and North Africa. Aleppo, Syria: ICARDA; 2005. pp. 141-93.

5. Sallam AM, Ibrahim AH, Alsheikh SM. Genetic evaluation of growth in Barki sheep using random regression models. Trop Anim Health Prod 2019;51:1893-901. https://doi.org/ 10.1007/s11250-019-01885-3

6. Sallam AM. Risk factors and genetic analysis of pre-weaning mortality in Barki lambs. Livest Sci 2019;230:103818. https:// doi.org/10.1016/j.livsci.2019.103818

7. Neibergs HL, Settles ML, Whitlock RH, Taylor JF. GSEA-SNP identifies genes associated with Johne's disease in cattle. Mamm Genome 2010;21:419-25. https://doi.org/10.1007/s00335010-9278-2

8. Sallam AM, Zare Y, Shook G, Collins M, Kirkpatrick BW. A positional candidate gene association analysis of susceptibility to paratuberculosis on bovine chromosome 7. Infect Genet Evol 2018;65:163-9. https://doi.org/10.1016/j.meegid. 2018.07.035

9. Sharma BS, Leyva I, Schenkel F, Karrow NA. Association of toll-like receptor 4 polymorphisms with somatic cell score and lactation persistency in Holstein bulls. J Dairy Sci 2006; 89:3626-35. https://doi.org/10.3168/jds.S0022-0302(06) 72402-X

10. Beecher C, Daly M, Childs S, et al. Polymorphisms in bovine immune genes and their associations with somatic cell count and milk production in dairy cattle. BMC Genet 2010;11:99. https://doi.org/10.1186/1471-2156-11-99

11. Noori R, Mahdavi AH, Edriss MA, Rahmani HR, Talebi M, Soltani-Ghombavani M. Association of polymorphism in exon 3 of toll-like receptor 4 gene with somatic cell score and milk production traits in Holstein dairy cows of Iran. S Afr J Anim Sci 2013;43:493-8. https://doi.org/10.4314/sajas. v43i4.6

12. Zhou H, Cheng L, Gong H, Byun SO, Edwards GR, Hickford JGH. Variation in the toll-like receptor 4 (TLR4) gene affects milk traits in dairy cows. J Dairy Res 2017;84:426-9. https:// doi.org/10.1017/S0022029917000711

13. Haile AB, Zhang W, Wang W, Yang D, Yi Y, Luo J. Fatty acid synthase (FASN) gene polymorphism and early lactation milk fat composition in Xinong Saanen goats. Small Rumin Res 2016;138:1-11. https://doi.org/10.1016/j.smallrumres. 2016.03.025

14. Oravcová M, Mačuhová $\mathrm{L}$, Tančin V. The relationship between somatic cells and milk traits, and their variation in dairy sheep breeds in Slovakia. J Anim Feed Sci 2018;27:97-104. https:// doi.org/10.22358/jafs/90015/2018

15. Ozmen O, Kul S. Identification of novel SNPs of ovine $P R L$ gene and their association with milk production traits. Russ J Genet 2016;52:977-84. https://doi.org/10.1134/S10227954 16090118

16. Balthazar CF, Pimentel TC, Ferrão LL, et al. Sheep milk: physicochemical characteristics and relevance for functional food development. Compr Rev Food Sci Food Saf 2017;16: 247-62. https://doi.org/10.1111/1541-4337.12250

17. Murphy TW, Berger YM, Holman PW, Baldin M, Burgett RL, Thomas DL. Factors affecting ewe performance in a crossbred dairy sheep research flock in the United States. J Anim Sci 2017;95:1892-9. https://doi.org/10.2527/jas.2016.1175

18. Bouallegue M, Haddad B, Aschi MS, Ben Hamouda M. Effect of environmental factors on lactation curves of milk production traits in Holstein-Friesian cows reared under North African conditions. Livest Res Rural Dev 2013;25:75.

18. Samson TI, Olajumoke OA. Genetic and non-genetic factors affecting yield and milk composition in goats. Adv Dairy Res 2017;5:1000175. https://doi.org/10.4172/2329-888X.1000175

20. Abd Allah M, Abass SF, Allam FM. Factors affecting the milk yield and composition of Rahmani and Chios sheep. Int J Livest Prod 2011;2:24-30.

21. Sezenler T, Ceyhan A, Yüksel MA, Önaldi AT, Yildirir M. Effect of parity and type of lambing on performance and udder traits of Bandirma ewes. Indian J Anim Sci 2016;86: 572-7.

22. Adegoke EO, Machebe NS, Ezekwe AG, Agaviezor OB. Effect of parity on changes in udder traits, milk yield and composition of West African dwarf sheep during lactation. Anim Prod Sci 2017;57:1047-57. https://doi.org/10.1071/AN15241

23. Zhou H, Hickford JGH, Fang Q, Lin YS. Allelic variation of the ovine Toll-like receptor 4 gene. Dev Comp Immunol 
2007;31:105-8. https://doi.org/10.1016/i.dci.2006.05.006

24. Zhou H, Hickford JGH, Gong H. Allelic variation of the caprine TLR4 gene identified by PCR-SSCP. Mol Cell Probes 2007;22:65-6. https://doi.org/10.1016/j.mcp.2007.08.003

25. Menzies M, Ingham A. Identification and expression of toll-like receptors 1-10 in selected bovine and ovine tissues. Vet Immunol Immunopathol 2006;109:22-30. https://doi.org/ 10.1016/j.vetimm.2005.06.014

26. Legarra A, Ugarte E. Genetic parameters of milk traits in Latxa dairy sheep. Anim Sci 2001;73:407-12. https://doi.org/10.1017/ S1357729800058379

27. Poulsen NA, Gregersen VR, Maciel GM, et al. Novel genetic variation associated to CSN3 strongly affects rennet-induced milk coagulation. Int Dairy J 2017;71:122-30. https://doi.org/ 10.1016/j.idairyj.2017.03.012

28. Li Y, Gao Y, Kim YS, Iqbal A, Kim JJ. A whole genome association study to detect additive and dominant single nucleotide polymorphisms for growth and carcass traits in Korean native cattle, Hanwoo. Asian-Australas J Anim Sci 2017;30:8-19. https://doi.org/10.5713/ajas.16.0170

29. Ibrahim AHM. Association of growth performance and body conformational traits with BMP4 gene variation in Barki lambs. Growth Factors 2019;37:153-63. https://doi.org/10. 1080/08977194.2019.1662417

30. Boysen TJ, Heuer C, Tetens J, Reinhardt F, Thaller G. Novel use of derived genotype probabilities to discover significant dominance effects for milk production traits in dairy cattle. Genetics 2013;193:431-42. https://doi.org/10.1534/genetics. 112.144535

31. Sharma BS, Abo-Ismail MK, Schenkel FS, et al. Association of TLR4 polymorphisms with mycobacterium avium subspecies paratuberculosis infection status in Canadian Holsteins. Anim Genet 2015;46:560-5. https://doi.org/10.1111/age.12333

32. He YY, Lawlor NT, Newburg DS. Human milk components modulate toll-like receptor-mediated inflammation. Adv Nutr 2016;7:102-11. https://doi.org/10.3945/an.115.010090 